\title{
Kesesuaian Parameter Fisika-Kimia Perairan Madong untuk Pengembangan Budidaya Rumput Laut Caulerpa sp
}

\section{Suitability on Physics and Chemistry Aspects of Madong Waters for Developt Cultivation of Seaweed Caulerpa sp}

\section{Tengku Said Razai ${ }^{1}$, Imam Pangestiansyah Putra ${ }^{2}$}

${ }^{1}$ Program Studi Budidaya Perairan, Universitas Maritim Raja Ali Haji. ${ }^{2}$ Laboratorium Oseanografi Kelautan, Universitas Maritim Raja Ali Haji. *Corespondent email: tengkusaidrazai@ gmail.com

Received: 16 June 2020 | Accepted: 21 August 2020 | Published: 27 August 2020

\begin{abstract}
Abstrak. Rumput laut Caulerpa $s p$ merupakan komoditas unggulan yang memiliki potensi ekonomi cukup besar. Pengembangan budidaya rumput laut Caulerpa sp. tidak terlepas dari kondisi parameter kualitas perairan. Keberhasilan kultur rumput laut dipengaruhi oleh beberapa faktor, terutama terkait dengan kondisi lingkungan perairan. Tujuan penelitian ini ialah menganalisis kesesuai kualitas perairan Madong untuk kegiatan budidaya rumput laut Caulerpa sp.. Penentuan lokasi sampling dilakukan secara acak untuk mewakili lokasi dari berbagai aktivitas masyarakat yang ada. Jumlah titik sampling ditentukan sebanyak 10 lokasi. Pembobotan parameter perairan dilakukan untuk mengatahui nilai kesesuaian dalam pengembangan budidaya rumput laut Caulerpa sp. Parameter-parameter yang diukur, diberi bobot dan skor sesuai dengan nilai hasil pengukurannya. Hasil penelitian menunjukkan perairan Madong sesuai untuk pengembangan budidaya rumput laut Caulerpa sp. Nilai kesesuaian diperoleh pada kisaran 46-49 dengan persentase kesesuaian antara 80,7-85,9 \%. Seluruh lokasi sampling dinyatakan tergolong pada tingkat kesesuaian yang tinggi (sesuai).

Kata kunci: Caulerpa sp, Kesesuaian, Parameter Fisika-kimia

Abstract. Caulerpa sp. seaweed is a superior commodity that has considerable economic potential. Cultivation development of seaweed Caulerpa sp. can not be separated from the condition of water quality parameters. The success of seaweed culture is influenced by several factors, especially those related to the condition of the aquatic environment. The purpose of this study was to analyze the suitability of the quality of Madong waters for the aquaculture of Caulerpa sp .. Determination of sampling locations was carried out randomly to represent the locations of various existing community activities. The number of sampling points is determined by 10 locations. Weighting of water parameters is carried out to determine the value of suitability in the development of aquaculture Caulerpa sp. The measured parameters are given weights and scores according to the value of the measurement results. The results showed that Madong waters are suitable for the development of seaweed cultivation of Caulerpa sp. The conformity value was obtained in the range of 46-49 with a suitability percentage between 80.7-85.9\%. All sampling locations are classified at a high level of suitability (appropriate). Keywords: Caulerpa sp, Suitability, Physics and Chemistry Aspects
\end{abstract}

\section{PENDAHULUAN}

Rumput laut jenis Caulerpa sp. tergolong ke dalam kelompok alga hijau (Chlorophyta) yang merupakan salah satu sumberdaya bernilai ekonomi (Bambaranda et al., 2019). Rumput laut Caulerpa sp. memiliki sebaran yang luas pada kawasan tropis dan subtropis (Chen et al., 2018). Caulerpa sp. saat ini dikembangkan menjadi komoditas budidaya yang memiliki nilai ekonomis tinggi. Bahkan beberapa riset menyebutkan bahwa Caulerpa sp. menjadi komoditas ekspor sebagai produk makanan, obat-obatan, kosmetik, dan produk makanan lainya (Tanduyan et al., 2013). Saat ini, pengembangan budidaya Caulerpa sp. di Indonesia terus mengalami 
peningkatan. Ferdiansyah et al., (2019) menyatakan bahwa potensi pengembangan rumput laut di Indonesia mencapai 1,11 juta ha dengan produksi diperkirakan mencapai sebesar 167.937 ton per tahun.

Caulerpa sp. juga dilaporkan tumbuh disebagian besar wilayah perairan Indonesia, termasuk ditemukan di beberapa perairan di Kepulauan Riau, diantaranya di perairan Pulau Bintan (Nurkiama et al., 2015). Perairan Madong merupakan salah satu kawasan perairan di Kota Tanjungpinang yang telah menjadi lokasi pengembangan budidaya berbagai komuniti hasil laut, terutama ikan. Perairan Madong sangat memungkinkan untuk dikembangkan menjadi kawasan budidaya rumput laut Caulerpa sp. sebagai komoditas baru selain ikan. Kawasan Madong merupakan kawasan dengan perairan yang lebih tenang, serta memiliki kondisi oseanografi yang mendukung sehingga layak untuk di kembangkan menjadi kawasan budidaya rumput laut. Rumput laut Caulerpa sp. berpotensi untuk meningkatkan ekonomi masyarakat sekitar.

Pengembangan budidaya rumput laut Caulerpa sp. tidak terlepas dari kondisi parameter kualitas perairan yang berpengaruh terhadap keberhasilan kultur dan pertumbuhan rumput laut. Terkait kualitas perairan pada budidaya rumput laut telah dilaporkan oleh peneliti sebelumnya. Waluyo et al., (2016) melaporkan bahwa produktivitas budidaya rumput laut sangat dipengaruhi oleh kualitas perairan. Kondisi alam menjadi faktor penting dalam pengembangan budidaya rumput laut (Noor, 2015). Pada prinsipnya budidaya rumput laut harus memilih tempat yang sesuai secara ekologi dengan kualitas perairan yang masih mendukung kelangsungan hidup rumput laut (Runtuboi et al., 2014).

Sementara itu, perairan Madong terdapat beberapa kegiatan antropogenik, yang tentunya berpengaruh terhadap kualitas perairan. Ismail et al., (2018) menyatakan bahwa perairan ini juga dimanfaatkan untuk berbagai macam aktivitas manusia antara lain kegiatan budidaya ikan dikeramba jaring apung, jalur pompong nelayan, restoran dan pemukiman. Dengan adanya aktivitas masyarakat di Kampung Madong, maka akan berpotensi menghasilkan limbah organik yang langsung masuk keperairan dan akhirnya berdampak pada kualitas air dan kesuburan perairan tersebut.

Pengembangan kawasan budidaya rumput laut harus didasari oleh kesesuaian parameter fisika-kimia perairan, untuk memperoleh hasil budidaya yang maksimal. Tujuan penelitian ini ialah untuk menganalisis kesesuai kualitas perairan Madong untuk kegiatan budidaya rumput laut Caulerpa sp.

\section{METODE PENELITIAN}

Penelitian ini dilakukan pada bulan Januari-April 2020 di perairan Madong, Kelurahan Kampung Bugis, Kecamatan Tanjungpinang Kota, Kota Tanjungpinang, Provinsi Kepulauan Riau. Analisis data parameter kualitas perairan dilakukan di Laboratorium kimia laut, Fakultas Ilmu Kelautan dan Perikanan, Universitas Maritim Raja Ali Haji. Alat-alat yang digunakan dalam penelitian diantaranya; multitester (suhu, $\mathrm{pH}$, dan DO), refractometer (salinitas), current meter (arus), fish finder (kedalaman), oven, timbangan analitik (substrat), dan spektrofotometer (nitrat, fosfat).

Pengambilan data dilakukan secara random sampling dengan perbedaan karakteristik/ kondisi lokasi. Rincian kondisi stasiun pengukuran yakni; stasiun 1 dan 2 pada kawasan sungai 
dekat permukiman, stasiun 3 dan 4 kawasan sungai dekat dengan lokasi budidaya ikan, stasiun 5 dan 6 pada kawasan sungai dekat area mangrove, stasiun 7, 8, 9 dan 10 kawasan muara sungai dekat dengan area penangkapan. Total titik sampling yang diamati sebanyak 10 titik sampling yang tersebar sepanjang aliran sungai hingga ke muara (Gambar 1).

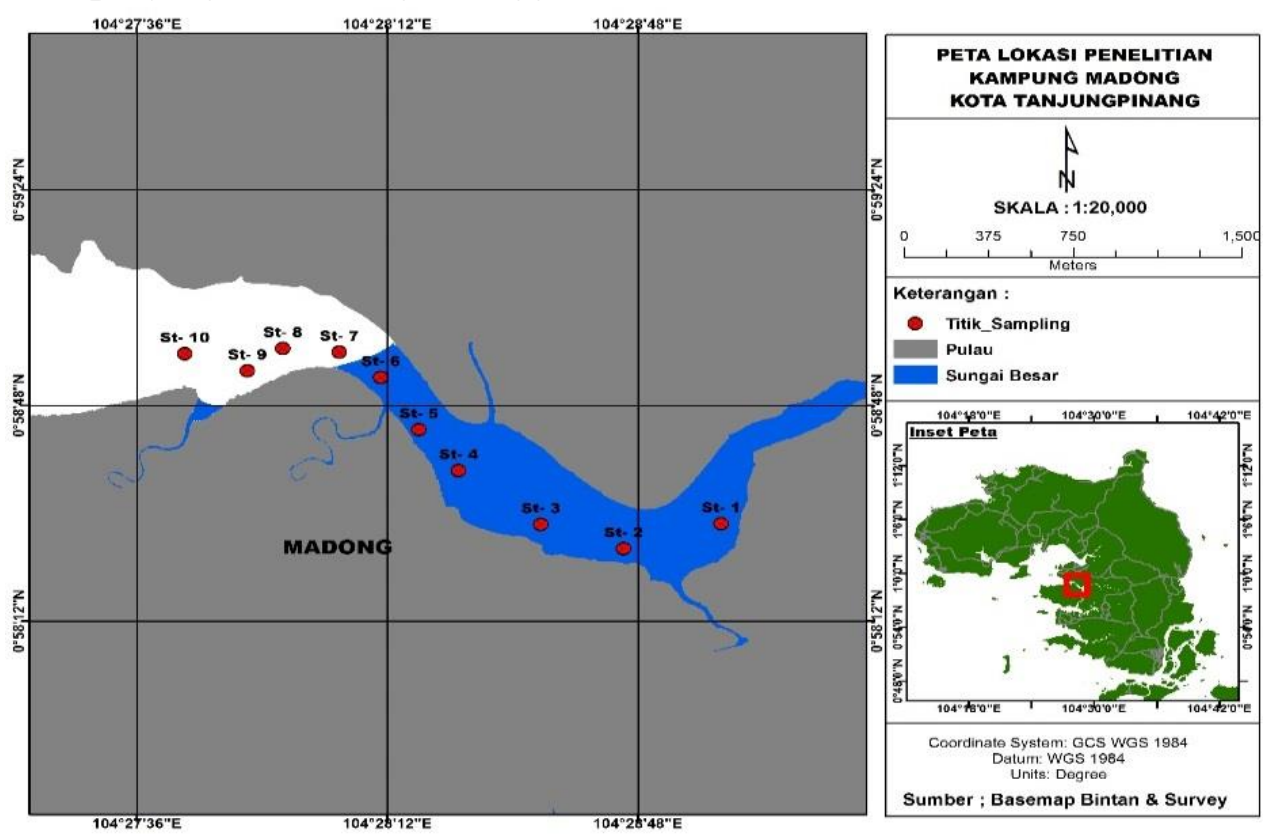

Gambar 1. Peta lokasi penambilan parameter fisika-kimia perairan Madong

\section{Prosedur Pengambilan Data}

Parameter kesesuaian budidaya yang diukur meliputi parameter fisika (arus, kedalaman, substrat, serta suhu), sedangkan parameter kimia (salinitas, $\mathrm{pH}$, DO, nitrat, serta fosfat). Parameter perairan diukur sebanyak tiga kali sampling selama penelitian. Nur et al. (2016) menyatakan bahwa kualitas air laut, suhu, kekeruhan, salinitas, $\mathrm{pH}$ air, oksigen terlarut, fosfat, dan tingkat kadar garam air laut sangat berpengaruh terhadap produksi rumput laut. Keseluruhan parameter perairan tersebut kemudian diberikan pembobotan sesuai dengan tingkat kesesuaianya yang tertera pada matriks kesesuaian. Parameter arus, kedalaman, suhu, salinitas, pH, DO dianalisis secara insitu, sedangkan substrat, nitrat dan fosfat dianalisis di laboratorium.

\section{Matriks Pembobotan Kesesuaian Perairan untuk Budidaya Caulerpa sp.}

Pembobotan parameter perairan dilakukan untuk mengatahui nilai kesesuaian yang diperoleh sehingga menjadi dasar dalam pengembangan budidaya rumput laut Caulerpa sp. Parameter yang diukur merupakan faktor pembatas kehidupan rumput laut (Radiarta et al., 2003) Parameter-parameter yang diukur, diberi bobot dan skor sesuai dengan nilai hasil pengukurannya dan diberi nilai sesuai dengan besar pengaruhnya (Runtuboi et al., 2014). Hasil pembobotan dan skor tersebut, digunakan untuk menentukan nilai kesesuaian parameter fisiks-kimia perairan untuk budidaya rumput laut Caulerpa sp, yang akan dikembangkan di perairan Madong. Untuk menentukan pembobotan paraemeter lingkungan, digunakan matrik kesesuaian seperti pada Tabel 1. 
Razai dan Putra. 2020. Kesesuaian parameter fisika-kimia perairan ...

Tabel 1. Matriks pembobotan kesesuaian kualitas perairan untuk budidaya Caulerpa sp di perairan Madong

\begin{tabular}{|c|c|c|c|c|c|c|}
\hline \multirow[t]{2}{*}{ Parameter } & \multirow[t]{2}{*}{ Satuan } & \multicolumn{3}{|c|}{ Skor } & \multirow[t]{2}{*}{ Bobot } & \multirow{2}{*}{$\begin{array}{l}\text { Sumber referensi } \\
\text { Bobot dan Skor }\end{array}$} \\
\hline & & Baik (3) & Sedang (2) & Buruk (1) & & \\
\hline Arus & $\mathrm{m} / \mathrm{detik}$ & $0,20-0,30$ & $\begin{array}{c}0,31-0,4 \text { dan } \\
0,1-0,19\end{array}$ & $<0,1$ dan $>0,4$ & 3 & $\begin{array}{l}\text { Runtuboi et al., } \\
\text { (2014) }\end{array}$ \\
\hline Kedalaman & $\mathrm{m}$ & $1-10$ & $11-15$ & $<1$ dan $>15$ & 2 & $\begin{array}{l}\text { Radiarta et al. } \\
\text { (2003); Jailani et } \\
\text { al., (2015) }\end{array}$ \\
\hline Substrat & fraksi & $\begin{array}{l}\text { Pasir atau } \\
\text { pecahan } \\
\text { karang }\end{array}$ & $\begin{array}{c}\text { Pasir } \\
\text { berlumpur }\end{array}$ & Lumpur & 2 & Noor (2015) \\
\hline Suhu & ${ }^{\circ} \mathrm{C}$ & $24-30$ & $20-24$ & $<20$ dan $>30$ & 3 & $\begin{array}{l}\text { Setiyanto et al., } \\
\text { (2008); Jailani et } \\
\text { al., (2015) }\end{array}$ \\
\hline Salinitas & $\%$ & $30-32$ & $\begin{array}{l}22-30 \text { dan } \\
32-34\end{array}$ & $<22$ dan $>34$ & 2 & $\begin{array}{l}\text { Waluyo et al. } \\
\text { (2016); Runtuboi } \\
\text { et al., (2014) }\end{array}$ \\
\hline $\mathrm{pH}$ & - & $6,5-8,5$ & $\begin{array}{c}5-6,4 \text { dan } \\
8,6-9\end{array}$ & $<5$ dan $>9$ & 1 & Noor (2015) \\
\hline DO & $\mathrm{mg} / \mathrm{l}$ & $>6$ & $4-6$ & $<4$ & 2 & $\begin{array}{l}\text { Jailani et al., } \\
\text { (2015) }\end{array}$ \\
\hline Nitrat & $\mathrm{mg} / \mathrm{l}$ & $0,2-0,5$ & $\begin{array}{c}0,1-02 \text { dan } 0,5- \\
0,1\end{array}$ & $<0,1$ dan $>1$ & 2 & $\begin{array}{l}\text { Ferdiansyah et al., } \\
\text { (2019); Waluyo et } \\
\text { al., (2016) }\end{array}$ \\
\hline Fosfat & $\mathrm{mg} / \mathrm{l}$ & $0,9-3,2$ & $\begin{array}{c}0,1-<0,9 \text { dan } \\
3,3-3,4\end{array}$ & $<0,1$ dan $>3,4$ & 2 & $\begin{array}{l}\text { Ferdiansyah et al., } \\
\text { (2019); Waluyo et } \\
\text { al., (2016) }\end{array}$ \\
\hline
\end{tabular}

\section{Analisis Kesesuaian Perairan untuk Budidaya Caulerpa sp. di Madong}

Untuk menganalisis tingkat kesesuaian perairan lokasi budidaya Caulerpa sp. dilakukan perhitungan indeks kesesuaian. Indeks kesesuaian dihitung untuk memperoleh persentase bobot dari semua parameter yang diukur. Jumlah nilai total dari semua parameter dihitung dengan rumus (Ferdiansyah et al., 2019):

$$
N=\sum(A \times B)
$$

Dimana $\mathrm{N}=$ Total bobot; $\mathrm{A}=$ Angka penilaian pada setiap kelas; $\mathrm{B}=$ Bobot pada setiap kelas. Untuk mengetahui tingkat kesesuaiannya digunakan rumus:

$$
I k=\frac{\left(\sum A \times \mathrm{B}\right)}{N \operatorname{Max}} \times 100 \%
$$

Dimana Ik= Indeks Kesesuaian, A= Angka penilaian pada setiap kelas, B= Bobot pada setiap kelas, N-max = Nilai maksimum. Setelah dihitung nilai kesesuaianya, disimpulkan hasil kesesuaian berdasarkan 3 kelas yakni; Nilai 0-33\% (tidak sesuai), 33-66\% (kurang sesuai), dan $66-100 \%$ (sesuai). 


\section{HASIL DAN PEMBAHASAN}

\section{Parameter Fisika}

Pengukuran kualitas perairan untuk menentukan kesesuaian lokasi budidaya Caulerpa $s p$ meliputi parameter fisika dan kimia. Parameter fisika yang diukur pada penelitian ini adalah, arus, kedalaman, dan suhu perairan. Hasil pengukuran parameter fisika disajikan pada Tabel 2. Tabel 2. Hasil pengukuran parameter fisika

\begin{tabular}{cccc}
\hline Stasiun & \multicolumn{3}{c}{ Parameter } \\
\cline { 2 - 4 } & Arus & Kedalaman & Suhu \\
\hline St. 1 & 0,238 & 2,58 & 30,1 \\
St. 2 & 0,273 & 2,46 & 30,4 \\
St. 3 & 0,247 & 1,90 & 29,8 \\
St. 4 & 0,243 & 1,96 & 29,1 \\
St. 5 & 0,272 & 2,60 & 29,9 \\
St. 6 & 0,237 & 2,58 & 29,5 \\
St. 7 & 0,224 & 2,51 & 29,8 \\
St. 8 & 0,265 & 2,62 & 29,9 \\
St. 9 & 0,211 & 2,82 & 29,8 \\
St. 10 & 0,231 & 2,70 & 30,1 \\
\hline Rerata & $\mathbf{0 , 2 4}$ & $\mathbf{2 , 4 7}$ & $\mathbf{2 9 , 8 4}$ \\
\hline Stdev & $\mathbf{0 , 0 2}$ & $\mathbf{0 , 3 0}$ & $\mathbf{0 , 3 5}$ \\
\hline
\end{tabular}

Arus permukaan merupakan parameter penting untuk menunjang kelangsungan budidaya rumput laut Caulerpa sp. Arus sangat menentukan distribusi nutrient yang mempengaruhi pertumbuhan rumput laut tersebut. Hasil pengukuran yang diperoleh, kondisi arus berkisar antara 0,21-0,27 m/s dengan rata-rata sebesar 0,24 m/s. Hasil penelitian Melsasail et al., (2018) juga memperoleh hasil bahwa arus pada lokasi budidaya rumput laut berkisar antara 0,15-0,29 m/s dengan kecepatan arus optimal yang baik bagi budidaya rumput laut berkisar antara $0,2-0,4 \mathrm{~m} / \mathrm{s}$. Nursidi et al., (2017) memperoleh kecepatan arus pada lokasi budidaya rumput laut berkisar 0,22-0,41 m/s, rumput laut memiliki kemampuan untuk hidup pada kisaran arus antara 0,05-0,20 $\mathrm{m} / \mathrm{s}$. Dari beberapa penelitian yang dilakukan, diketahuhi bahwa kondisi arus di perairan Madong tergolong baik bagi kehidupan rumput laut Caulerpa sp. Kedalaman perairan pada titik sampling berkisar antara 1,9-2,8 m dengan rata-rata 2,47 m. Rabia (2016) menyatakan bahwa jenis rumput laut Caulerpa sp tumbuh pada perairan dengan kedalaman antara 1,2-1,5 m. Meskipun demikian jenis rumput laut Caulerpa sp masih dijumpai hingga kedalaman 10-50 m, namun pada kegiatan budidaya umumnya dilakukan pada kedalaman 0,5 m (Aziz et al., 2019).

Suhu di lokasi penelitian tercatat berkisar antara $29,1-30,4{ }^{\circ} \mathrm{C}$ dengan rata-rata suhu sebesar $29,84^{\circ} \mathrm{C}$. Gao et al., (2019) melakukan ekperimen perbedaan suhu terhadap pertumbuhan Caulerpa sp dengan perlakuan suhu $15^{\circ} \mathrm{C}, 20^{\circ} \mathrm{C}, 25^{\circ} \mathrm{C}$, dan $30{ }^{\circ} \mathrm{C}$, hasilnya menunjukkan bahwa pertumbuhan optimal pada suhu $25^{\circ} \mathrm{C}$. Ukabi et al., (2015) menyatakan bahwa Caulerpa sp hidup pada kisaran suhu antara $27-32^{\circ} \mathrm{C}$, sedangkan Rabia (2016) Caulerpa sp hidup pada suhu antara $28-31{ }^{\circ} \mathrm{C}$. Secara keseluruhan, kondisi suhu di lapangan selama pelaksanaan penelitian masih sangat mendukung kehidupan rumput laut Caulerpa sp. Kondisi suhu sangat erat pengaruhnya dengan perubahan faktor iklim selama penelitian, pada saat pengambilan data 
diambil pada saat musim panas sehingga suhu lebih tinggi, namun secara keseluruhan masih sesuai dengan kisaran kehidupan rumput laut Caulerpa sp. Selain faktor fisika, faktor kimia juga di ukur selama penelitian meliputi; salinitas, $\mathrm{pH}$, oksigen terlarut, nitrat, serta fosfat.

Tabel 3. Hasil pengukuran parameter kimia

\begin{tabular}{cccccc}
\hline \multirow{2}{*}{ Stasiun } & \multicolumn{5}{c}{ Parameter } \\
\cline { 2 - 6 } & Salinitas & pH & DO & Nitrat & Fosfat \\
\hline St. 1 & 25 & 6,99 & 5,2 & 0,29 & 0,01 \\
St. 2 & 25 & 6,93 & 5,5 & 0,24 & 0,01 \\
St. 3 & 25 & 6,96 & 5,2 & 0,22 & 0,04 \\
St. 4 & 25 & 7,01 & 5,7 & 0,27 & 0,023 \\
St. 5 & 27 & 7,14 & 5,7 & 0,32 & 0,01 \\
St. 6 & 29 & 6,97 & 6,5 & 0,23 & 0,01 \\
St. 7 & 29 & 7,01 & 6,4 & 0,27 & 0,053 \\
St. 8 & 29 & 7,15 & 6,4 & 0,28 & 0,038 \\
St. 9 & 30 & 6,9 & 6,3 & 0,29 & 0,027 \\
St. 10 & 30 & 6,86 & 6,2 & 0,23 & 0,06 \\
\hline Rerata & $\mathbf{2 7 , 4 0}$ & $\mathbf{6 , 9 9}$ & $\mathbf{5 , 9 1}$ & $\mathbf{0 , 2 6}$ & $\mathbf{0 , 0 3}$ \\
Stdev & $\mathbf{2 , 2 2}$ & $\mathbf{0 , 0 9}$ & $\mathbf{0 , 5 1}$ & $\mathbf{0 , 0 3}$ & $\mathbf{0 , 0 2}$ \\
\hline
\end{tabular}

Hasil pengukuran parameter salinitas menunjukkan pada kisaran 25-30 ppt dengan ratarata 27,4 ppt. Jenis rumput laut Caulerpa sp tumbuh optimal pada salinitas sebesar $30 \mathrm{ppt}$ (Gao et al., 2019). Rumput laut Caulerpa sp mampu hidup pada kisaran salinitas yang luas antara 20$50 \mathrm{ppt}$, namun fotosintesis terjadi pada salinitas antara 25-45ppt, pertumbuhan optimum Cauluerpa terjadi pada salinitas yang tidak melebihi 35 ppt (Hui et al., 2015). Murillo dan Salamanca (2016) mengungkapkan bahwa kisaran salinitas untuk pertumbuhan Caulerpa sp antara 25-30 ppt, pada kisaran salinitas tersebut Caulerpa sp mengalami peneambahan biomass dan perkembangan stolon. Nurfebriani et al. (2015) menyatakan bahwa Caulerpa sp tumbuh pada kisaran salinitas antara 25-34 ppt.

Penelitian Nursidi et al., (2017) memperoleh hasil, bahwa pada salinitas 31-32 ppt mengalami pertumbuhan optimum sebesar 1,23 gram/hari. Mengacu pada beberapa penelitian dan kajian terdahulu, bahwa kondisi salinitas di lokasi penelitian masih mendukung kehidupan rumput laut Caulerpa sp. Pereira et al., (2017) menyatakan bahwa rumput laut pada umumnya hidup pada kisaran salinitas antara 25-40 ppt. Dengan demikian kondisi salinitas di perairan Madong masih sesuai dengan baku mutu yang mengacu pada Kep Men LH Nomor 51 (2004).

Derajat keasaman di perairan Madong berkisar antara 6,8-7,15 dengan rata-rata 6,9. Kualitas air untuk parameter $\mathrm{pH}$ yang sesuai bagi kehidupan rumput laut Caulerpa sp yakni berkisar 7,6-8 (Zuldin et al., 2019), pendapat lain menyatakan $\mathrm{pH}$ untuk rumput laut Caulerpa sp antara 7,9-8,4 (Rabia, 2016), dan Nurfebrianti et al., (2015) menyatakan kondisi derajat keasaman pada lokasi budidaya rumput laut Caulerpa sp antara 8-9. Kondisi pH di perairan Madong masih sesuai dengan derajat keasaman untuk kehidupan rumput laut Caulerpa $s p$ sehingga masih sesuai. Oksigen terlarut di lokasi penelitian tercatat berkisar antara 5,2-6,5 mg/l dengan rata-rata sebesar $5,9 \mathrm{mg} / \mathrm{l}$. Oksigen terlarut yang sesuai bagi kehidupan rumput laut Caulerpa sp yakni berkisar 4,7-5,2 mg/l (Zuldin et al., 2019). Pulukadang et al., (2013) mengatakan bahwa kandungan oksigen terlarut di lokasi penelitian berkisar antara 4,7-4,8 mg/l. Kondisi oksigen terlarut secara keseluruhan masih sesuai dengan kebutuhan perairan untuk 
budidaya rumput laut Caulerpa sp. Namun, oksigen terlarut dipengaruhi oleh cuaca terutama peningkatan suhu perairan. Sesuai dengan pendapat Sunyer et al., (2012) bahwa peningkatan suhu akan menyebabkan terjadinya penurunan kadar oksigen diperairan.

Konsentrasi nitrat di lokasi penelitian berkisar antara 0,23-0,32 mg/l dengan rata-rata 0,26 $\mathrm{mg} / \mathrm{l}$, sedangkan konsentrasi fosfat berkisar antara 0,01-0,05 mg/l dengan rata-rata 0,03 mg/l. Zuldin et al., (2019) konsentrasi nitrat yang mendung untuk kehidupan rumput laut Caulerpa sp yakni > 0,1 mg/l. Penelitian Alamsyah (2016) di lokasi budidaya rumput laut Kabupaten Sinjai memperoleh hasil pengukuran nitrat berkisar $0,21-0,37 \mathrm{mg} / \mathrm{l}$ dan fosfat $0,01-0,04 \mathrm{mg} / \mathrm{l}$, pada penelitian tersebut, konsentrasi nitrat $>1,6-3,5 \mathrm{mg} / \mathrm{l}$ dan fosfat $>0,20 \mathrm{mg} / \mathrm{l}$ mendukung untuk pengembangan budidaya rumput laut. Data menunjukkan bahwa nilai nitrat dan fosfat di perairan Madong cukup mendukung kebutuhan budidaya rumput laut Caulerpa sp. Pada prinsipnya rumput laut membutuhkan nitrat dan fosfat untuk mendukung pertumbuhan, produksi pigmen, fotosintesis dan kadar protein (Martins et al., 2011; Liu et al., 2016).

\section{Kesesuaian Lingkungan Perairan Untuk Budidaya Rumput Laut Caulerpa sp.}

Setelah pengukuran parameter kualitas perairan disemua stasiun penelitian, selanjutnya dilakukan pembobotan nilai parameter kualitas perairan untuk mengatahui nilai kesesuaian perairan dalam pengembangan budidaya rumput laut Caulerpa sp.. Panduan nilai pembobotan (skor) untuk setiap parameter mengacu pada matriks kesesuaian pada Tabel 1. Tingkat kesesuaian perairan untuk budidaya rumput laut Caulerpa sp di perairan Madong disajikan pada Tabel 4.

Tabel 4. Pembobotan kesesuaian perairan Madong untuk budidaya Rumput Laut Caulerpa sp ditinjau dari parameter fisika dan kimia perairan

\begin{tabular}{cccc}
\hline Stasiun & Total Nilai & -Persentase $(\boldsymbol{\%})$ & Keputusan \\
\hline St. 1 & 46 & 80,70 & Sesuai \\
St. 2 & 46 & 80,70 & Sesuai \\
St. 3 & 49 & 85,96 & Sesuai \\
St. 4 & 47 & 82,46 & Sesuai \\
St. 5 & 49 & 85,96 & Sesuai \\
St. 6 & 49 & 85,96 & Sesuai \\
St. 7 & 47 & 82,46 & Sesuai \\
St. 8 & 47 & 82,46 & Sesuai \\
St. 9 & 49 & 85,96 & Sesuai \\
St. 10 & 49 & 85,96 & Sesuai \\
\hline Rerata & $\mathbf{4 7 , 8}$ & $\mathbf{8 3 , 8 6}$ & Sesuai \\
\hline
\end{tabular}

Hasil analisis kesesuaian menunjukkan bahwa nilai skor kesesuaian pada kisaran 46-49 poin dengan persentase kesesuaian antara 80,7-85,9 \%. Seluruh lokasi sampling tergolong pada tingkat kesesuaian yang tinggi. Penelitian yang dilakukan oleh Alamsyah (2016) memperoleh nilai kesesuaian berkisar 53-62 poin dengan kategori sesuai. Sedangkan Akib et al., (2015) memperoleh nilai kesesuaian budidaya rumput laut berkisar $69-76 \%$ dengan kategori cukup sesuai hingga sesuai. 
Berdasarkan hasil analisis kesesuaian ini, perairan Madong dapat dikembangkan menjadi kawasan budidaya rumput laut Caulerpa $s p$. Budidaya rumput laut Caulerpa sp di perairan Madong dapat dilakukan dengan metode kultur bersama (multi spesies) yang dikombinasikan dengan budidaya ikan yang saat ini telah dilakukan di perairan Madong. Hal ini sangat memungkinkan karena Caulerpa sp selain menjadi komoditas budidaya juga memiliki kemampuan mendegradasi limbah organik yang dihasilkan dari kegiatan budidaya perikanan (ikan). Kedalaman, kecerahan, nitrat, fosfat, salinitas, dan suhu menjadi parameter penting untuk menentukan kesesuaian perairan budidaya rumput laut. Menurut Dewanto et al., (2015) bahwa kedalaman air, kecerahan air dan arus faktor pembatas budidaya rumput laut Caulerpa.

\section{KESIMPULAN}

Hasil pengukuran dan analisis kesesuaian terhadap parameter fisika dan kimia, perairan Madong tergolong dalam kategori sesuai untuk pengembangan budidaya Caulerpa sp dengan nilai kesesuaian antara 46-49 dan persentase kesesuaian sebesar 80,7-85,96\%. Seluruh parameter pada semua lokasi sampling dinyatakan tergolong pada tingat kesesuaian yang tinggi. Perairan Madong dapat dikembangkan menjadi kawasan budidaya Caulerpa sp. Diperlukan penelitian lanjutan yang mengkaji kesesuaian aspek sosial ekonomi masyarakat sekitar sehingga informasi tentang status kesesuaian perairan Madong untuk pengembangan budidaya Caulerpa sp lebih lengkap.

\section{REFERENSI}

Akib, A., Litaay, M., Ambeng, and Asnady, M. 2015. Water Quality Fitness for Cultivation of Eucheuma cottoni based on Physics, Chemitstry and Biology Aspects In District Islands Selayar. Jurnal Pesisir dan Laut Tropis, 1 (1): 25-36.

Alamsyah, R. 2016. Kesesuaian Parameter Kualitas Air untuk Budidaya Rumput Laut di Desa Panaikang Kabupaten Sinjai. Jurnal Agrominansia, 1 (2): 61-70.

Aziz, H. Y., Karim, M. Y., Amri, K., and Hasbullah, D. 2019. Productivity of several Caulerpa species grown in fishponds. Bioflux, 11 (1): 21-24.

Bambaranda, B. V., Tsukaka, T. W., Chirapart, A., Salin, K. R., and Sasaki, N. 2019. Capacity of Caulerpa sp lentillifera in the Removal of Fish Culture Effluent in a Recirculating Aquaculture System. Processes, 7 (440): 1-15.

Chen, X., Sun, Y., Liu, H., Liu, S., Qin, Y., and Li, P. 2018. Advances in cultivation, wastewater treatment application, bioactive components of Caulerpa splentillifera and their biotechnological application. Peer,10 (7717): 1-15.

Dewanto, Y. B., Saifullah, dan Hermawan, D. 2015. Evaluation of Suitability Area for Development of Seaweed Culture (Kappaphycus alvarezii) at Lontar village, District Tirtayasa, Serang. Jurnal Perikanan dan Kelautan, 5 (2): 49-55.

Ferdiansyah, H. I., Pratikno, I., dan Suryono. 2019. Pemetaan Kesesuaian Lahan Untuk Budidaya Rumput Laut Di Perairan Pulau Poteran, Kabupaten Sumenep, Jawa Timur. Journal of Marine Research, 8 (1): 36-40.

Gao, X., Choi, H.G., Park, S.K., Sun, Z.M., and Nam, K.W. 2019. Assessment of optimal growth conditions for cultivation of the edible Caulerpa okamurae (Caulerpales, Chlorophyta) from Korea. Journal of Applied Phycology, 31: 1855-1862. 
Hui, G., Zhongmin, S., and Delin, D. 2014. Effect of Salinity and Nutrients on the Growth and Chlorophyll Fluorescence of Caulerpa lentillifera. Chinese Journal of Oceanology and Limnology 33(2) : 410 418

Ismail, Melani, W.R., dan Apriadi, T. 2018. Tingkat Kesuburan Perairan di Perairan Kampung Madong, Kelurahan Kampung Bugis, Kota Tanjungpinang. Jurnal Akuatik Lestari, 2 (1): 9-13.

Jailani, A. Q., Herawati, E. Y., and Semedi, B. 2015. Feasibility Study of Eucheuma Cottonii Seaweed Farming in Bluto Subdistrict of Sumenep Madura East Java. Jurnal Manusia dan Lingkungan, 22 (2): 211-216.

Liu, H., Wang, F., Wang, Q., Dong, S., and Tian, X. 2016. A comparative study of the nutrient uptake and growth capacities of seaweeds Caulerpa lentillifera and Gracilaria lichenoides. Journal of Applied Phycology 28: 3083-3089.

Martins, A.P., Junior, O.N., Colepicolo, P., and Yokoya, N.S. 2011. Effects of nitrate and phosphate availabilities on growth, photosynthesis and pigment and protein contents in colour strains of Hypnea musciformis (Wulfen in Jacqu.) J.V. Lamour. (Gigartinales, Rhodophyta). Rev. Bras. Farmacogn 21(2), 1-18.

Melsasail, K., Awan, A., Papilaya, P. M., and Rumahlatu, D. 2018. The ecological structure of macroalgae community (seagrass) on various zones in the coastal waters of Nusalaut Island, Central Maluku District, Indonesia. Bioflux 11 (4) : 957-966.

Murillo, M.Z, and Salamanca, E.J. 2016. Effect of salinity on growth of the green alga Caulerpa sertularioides (Bryopsidales, Chlorophyta) under laboratory conditions. Hidrobiologica 26 (2) : 277-282.

Nursidi, Mauli, and Heriansah. 2017. Development of seaweed Kappaphycus alvarezii cultivation through vertical method in the water of small islands in South Sulawesi, Indonesia. Bioflux, 10 (6): 1428-1435.

Noor, N.M. 2015. Analisis Kesesuaian Perairan Ketapang, Lampung Selatan Sebagai Lahan Budidaya Rumput Laut Kappapycus alvarezii. Maspari Journal, 7 (2): 91-100.

Nur, A.I., Syam, H., dan Patang. 2016. Pengaruh Kualitas Air Terhadap Produksi Rumput Laut (Kappaphycus alvarezii). Jurnal Pendidikan Teknologi Pertanian 2 : 27-40.

Nurfebrianti, D., Rejeki, S., and Widowati, L.L. 2015. The Effect of Liquid Organic Fertilizer Administration with Different Immersion Duration to Seaweed (Caulerpa lentillifera) Growth. Journal of Aquaculture Management and Technology, 4 (4): 88-94.

Nurkiama, L., Muzahar, dan Idris, F. 2015. Keanekaragaman dan Pola Sebaran Makroalga di Perairan Laut Pulau Pucung Desa Malang Rapat Kabupaten Bintan. Jurnal UMRAH : 1-14

Pereira, D. T., Simioni. C., Filipin, E.P., Bouvie, F., Ramlov, F., Maraschin, M., Bouzon, Z.L., and Schmidt, C. 2017. Eff ects of salinity on the physiology of the red macroalga, Acanthophora spicifera (Rhodophyta, Ceramiales). Acta Botanica Brasilica, 31 (4): 555565 .

Pulukadang, I., Keppel, R.C., dan Gerung, G.S. 2013. A study on bioecology of macroalgae, genus Caulerpa sp in northern Minahasa Waters, North Sulawesi Province. Aquatic Science \& Management, 1 (1): 26-31. 
Razai dan Putra. 2020. Kesesuaian parameter fisika-kimia perairan ...

Rabia, M.D.S. 2016. Cultivation of Caulerpa lentillifera Using Tray and Sowing Methods in Brackishwater Pon. Environmental Sciences, 4 (1): 23 - 29.

Radiarta, I., Wardoyo, S.E., Priyono, B., dan Praseno, O. 2003. Aplikasi Sistem Informasi Geografis untuk Penentuan Lokasi Pengembangan Budidaya Laut di Teluk Ekas, Nusa Tenggara Barat. Jurnal Penelitian Perikanan Indonesia, 9(1): 67-71.

Runtuboi, D., Paulungan, Y. P., dan Gunaedi, D. T. 2014. Studi Kesesuaian Lahan Budidaya Rumput Laut Berdasarkan Parameter Biofisik Perairan di Yensawai Distrik Batanta Utara Kabupaten Raja Ampat. Jurnal Biologi Papua, 6 (1): 31-37.

Setiyanto, D., Efendi, I. dan Antara, K.J. 2008. Pertumbuhan Kappaphycus alvarezii var Maumare, var Sacol dan Eucheuma cottonii di Perairan Musi Buleleng. Jurnal Ilmu Kelautan, 13(3): 171-176.

Sunyer, R.V., Duarte, C. M., Jorda, G., and Halpern, S.R. 2012. Temperature Dependence of Oxygen Dynamics and Community Metabolism in a Shallow Mediterranean Macroalgal Meadow (Caulerpa prolifera). Estuaries and Coasts, 35: 1182-1192.

Tanduyan, S.N., Gonzaga, R.B., and Bensig, V.D., 2013. Off bottom culture of Caulerpa sp lentillifera in three different water levels in the marine waters of San Francisco, Cebu, Philippines. Proc 2nd APCRS. Galaxea, Journal of Coral Reff Studies, (Special Issue): 123-132.

Waluyo, Yonvitner, Riani, E., dan Arifin, T. 2016. Daya Dukung Perairan Untuk Pengembangan Budidaya Rumput Laut Eucheuma cottonii Di Kabupaten Luwu Dan Kota Palopo, Teluk Bone, Sulawesi Selatan. Jurnal Ilmu dan Teknologi Kelautan Tropis, 8 (2): 469-492.

Zuldin, W. H., Shaleh, S. R. M., and Shapawi, R. 2019. Growth, Biomass Yield, and Proximate Composition of Sea Vegetable, Caulerpa macrodisca (Bryopsidales, Chlorophyta) Cultured in Tank. Philippine Journal of Science, 148 (1): 1-6.

\section{Authors:}

Tengku Said Razai, Program Studi Budidaya Perairan, Universitas Maritim Raja Ali Haji, Jl. Politeknik Kampus Senggarang, 24122, Kepulauan Riau, Indonesia, email: tengkusaidrazai@gmail.com

Imam Pangestiansyah Putra, Laboratorium Oseanografi Kelautan, Universitas Maritim Raja Ali Haji, Jl. Politeknik Kampus Senggarang, 24122, Kepulauan Riau, Indonesia, email: putraimam011@gmail.com

This is an open-access article distributed under the terms of the Creative Commons Attribution License, which permits unrestricted use, distribution and reproduction in any medium, provided the original author and source are credited. (http://creativecommons.org/licenses/by/4.0/).

\section{How to cite this article:}

Razai, T.S., and Putra, I.P. 2020. Suitability on physics and chemistry aspects of madong waters for developt cultivation of seaweed Caulerpa sp. Simbiosa, 9(2): 97-106. Doi. http://dx.doi.org/10.33373/sim-bio.v9i2.2499 